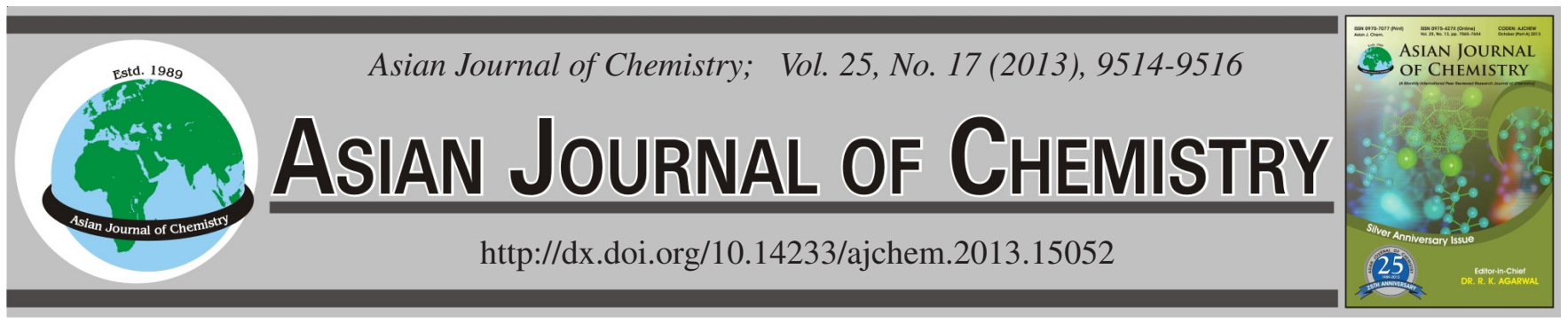

\title{
Antiviral Fluorenone Derivatives from Arundina gramnifolia
}

De-Yun Niu ${ }^{1,2}$, Jing-Mei Han², Wei-Song Kong ${ }^{2}$, Zhu-Wen CuI 2 , Qiu-Fen Hu' ${ }^{1}$ and Xue-Mei Gai ${ }^{1, *}$

${ }^{1}$ Key Laboratory of Chemistry in Ethnic Medicinal Resources, State Ethnic Affairs Commission \& Ministry of Education, Yunnan University of Nationalities, Kunming 650031, P.R. China

${ }^{2}$ Key Laboratory of Tobacco Chemistry of Yunnan Province, Yunnan Academy of Tobacco Science, Kunming 650106, P.R. China

*Corresponding authors: E-mail: gao_xuemei@hotmail.com

A new fluorenone derivative, gramniphenol H (1), together with four known fluorenone derivatives (2-5) were isolated from the whole plant of Arundina gramnifolia. Their structures were determined by means of HRESIMS, extensive 1D and 2D NMR spectroscopic studies and chemical evidence. Compound $\mathbf{1}$ was tested for its cytotoxicity against five human tumor cell lines and it shows modest cytotoxicity against PC3 and SHSY5Y cell with $\mathrm{IC}_{50}$ values of 6.18 and $4.25 \mu \mathrm{M}$, respectively.

Key Words: Arundina gramnifolia, Fluorenone, Structural elucidation, Cytotoxicity.

\section{INTRODUCTION}

Arundina gramnifolia (D. Don) Hochr. (bamboo orchid) belongs to the orchid family (Orchidaceae). The plant is used in Chinese folkloric medicine as a detoxifying and diuretic agent, as well as for the treatment of arthritis and inflammation $^{1}$. Previous phytochemical studies on A. gramnifolia has revealed the presence of stilbenoids ${ }^{2-4}$, sterols ${ }^{5,6}$, triterpenes ${ }^{7,8}$ and phenols ${ }^{5-10}$.

In our previous studies, some new phenols possessing antitobacco mosaic virus (anti TMV) property were isolated from A. gramnifolia ${ }^{9,10}$. Continuing the efforts to discover bioactive metabolites from local plants, we now investigated the chemical constituents of the whole plant of A. gramnifolia growing in the Xishuangbanna Prefecture, leading to the isolation of a new fluorenone derivative (1) and four known fluorenone derivatives (2-5). The structures of the isolated compounds were determined by means of spectroscopic methods including 1D and 2D NMR techniques. Compound 1 was tested for its cytotoxicity against five human tumor cell lines and it shows modest cytotoxicity against PC3 and SHSY5Y cell.

\section{EXPERIMENTAL}

General procedures: Optical rotations were measured in a Horiba SEPA-300 polarimeter. UV spectra were obtained on a Shimadzu UV-2401A spectrophotometer and CD spectra were measured on a JASCO J-810 spectropolarimeter. Tenor 27 spectrophotometer was used for scanning IR spectra $(\mathrm{KBr}$ pellets). 1D and 2D NMR spectra were recorded on a DRX500 spectrometer with TMS as internal standard. Chemical shifts $(\delta)$ were expressed in ppm with reference to TMS. HRESIMS was performed on an API QSTAR spectrometer or a VG Autospec-3000 spectrometer. Preparative HPLC was performed on a Shimadzu LC-8A liquid chromatography equipped with ZORBAX PrepHT GF $(21.2 \mathrm{~mm} \times 25 \mathrm{~cm}, 7 \mu \mathrm{m})$ column or Venusil MP $\mathrm{C}_{18}(20 \mathrm{~mm} \times 25 \mathrm{~cm}, 5 \mu \mathrm{m})$ column. Column chromatography was performed using Si gel (200300 mesh, Qing-dao Marine Chemical, Inc., Qingdao, China), Lichroprep RP-18 gel (40-63 $\mu \mathrm{M}$, Merck, Darmstadt, Germany), Sephadex LH-20 (Sigma-Aldrich, Inc, USA) or MCI gel (75-150 $\mu \mathrm{M}$, Mitsubishi Chemical Corporation, Tokyo, Japan). Column fractions were monitored by TLC and the spots were visualized by heating the plates after spraying with $5 \% \mathrm{H}_{2} \mathrm{SO}_{4}$ in $\mathrm{EtOH}$.

The whole plant of Arundina gramnifolia (D. Don)Hochr. was collected in the Xishuangbanna prefecture of Yunnan Province in in September 2010. The identification of plant material was verified by Prof. Ning Yuan. A voucher specimen (Ynni-10-09-22) has been deposited in the Key Laboratory of Chemistry of Ethnic Medicinal Resources, Yunnan University of Nationalities.

Extraction and isolation: The air-dried and powdered of whole plant of A. gramnifolia $(2.0 \mathrm{~kg})$ were extracted three times with $70 \%$ aqueous acetone $(3.0 \mathrm{~L} \times 3.5 \mathrm{~L})$ at room temperature and filtered to yield a filtrate, which was successively evaporated under reduced pressure to obtain a crude extract (152 g). The extract was applied to silica gel (150-200 
mesh) column chromatography, eluting with $\mathrm{CHCl}_{3}-\mathrm{MeOH}$ gradients $(20: 1,9: 1,8: 2,7: 3,6: 4,5: 5)$ to afford fractions A-F. Further separation of fraction B (35.4 g) by silica gel (300400 mesh), eluted with $\mathrm{CHCl}_{3}-\mathrm{CO}\left(\mathrm{CH}_{3}\right)_{2}$ (9:1-1:2), yielded fractions B1-B7. Fraction B3 (5.72 g), upon further separation on silica gel using petroleum ether- $\mathrm{CH}_{3} \mathrm{COOC}_{2} \mathrm{H}_{5}$ and semipreparative $\mathrm{HPLC}\left(55 \% \mathrm{MeOH}-\mathrm{H}_{2} \mathrm{O}\right.$, flow rate $\left.12 \mathrm{~mL} / \mathrm{min}\right)$, afforded 1 (18.2 mg), 2 (16.7 mg), $3(21.4 \mathrm{mg}) \mathbf{4}(28.2 \mathrm{mg}$ and 5 (29.7 mg).

Gramniphenol H (1): Red gum; $[\alpha]_{\mathrm{D}}{ }^{25.0}-16.8$ (c 0.25 , $\left.\mathrm{CH}_{3} \mathrm{OH}\right)$; UV $\left(\mathrm{CH}_{3} \mathrm{OH}\right) \lambda_{\max }(\log \varepsilon) 210$ (3.72), 267 (3.88), 320 (2.52), 346 (2.71) nm; IR (KBr, $\left.v_{\max }, \mathrm{cm}^{-1}\right)$ : 3325, 2970, 2892, 1694, 1612, 1547, 1455, 1184, $1119 ;{ }^{1} \mathrm{C}$ and ${ }^{13} \mathrm{H}$ NMR data $\left(\mathrm{C}_{5} \mathrm{D}_{5} \mathrm{~N}, 500\right.$ and $\left.125 \mathrm{MHz}\right)$ see Table-1; negative ESIMS $\mathrm{m} / z 327$ [M-H] $^{-}$; negative HRESIMS m/z $327.0862[\mathrm{M}-\mathrm{H}]^{-}$ (calcd. (\%) for $\mathrm{C}_{18} \mathrm{H}_{15} \mathrm{O}_{6}, 327.0869$ ).

\begin{tabular}{|c|c|c|}
\hline \multicolumn{3}{|c|}{$\begin{array}{c}\text { TABLE-1 } \\
{ }^{1} \mathrm{H} \text { AND }{ }^{13} \mathrm{C} \text { NMR DATA OF COMPOUND } 1\left(\delta \text { IN ppm, IN } \mathrm{C}_{5} \mathrm{D}_{5} \mathrm{~N}\right) \\
\end{array}$} \\
\hline \multirow{2}{*}{ Position } & \multicolumn{2}{|c|}{ Compound $\mathbf{2}$} \\
\hline & $\delta_{\mathrm{C}}$ & $\delta_{\mathrm{H}}(\mathrm{J}$ in $\mathrm{Hz})$ \\
\hline 1 & $150.8 \mathrm{~s}$ & - \\
\hline 2 & $118.2 \mathrm{~d}$ & $6.71 \mathrm{~d}(8.8)$ \\
\hline 3 & $129.5 \mathrm{~d}$ & $7.06 \mathrm{~d}(8.8)$ \\
\hline 4 & $144.4 \mathrm{~s}$ & - \\
\hline 5 & $156.6 \mathrm{~s}$ & - \\
\hline 6 & $106.9 \mathrm{~d}$ & $6.91 \mathrm{~s}$ \\
\hline 7 & $154.5 \mathrm{~s}$ & - \\
\hline 8 & $108.1 \mathrm{~d}$ & $6.77 \mathrm{~s}$ \\
\hline 9 & $192.9 \mathrm{~s}$ & - \\
\hline $4 a$ & $125.0 \mathrm{~s}$ & - \\
\hline $4 \mathrm{~b}$ & $120.6 \mathrm{~s}$ & - \\
\hline $8 \mathrm{a}$ & $137.1 \mathrm{~s}$ & - \\
\hline $9 \mathrm{a}$ & $116.8 \mathrm{~s}$ & - \\
\hline $1^{\prime}$ & $71.0 \mathrm{t}$ & $3.97 \mathrm{dd}(6.9,10.0)$ \\
\hline- & - & $4.13 \mathrm{dd}(9.5,4.0)$ \\
\hline $2^{\prime}$ & $74.1 \mathrm{~d}$ & $4.36 \mathrm{~m}$ \\
\hline $3^{\prime}$ & $145.8 \mathrm{~s}$ & \\
\hline $4^{\prime}$ & $113.4 \mathrm{t}$ & $4.89 \mathrm{~s}$ \\
\hline- & - & $5.18 \mathrm{~s}$ \\
\hline $5^{\prime}$ & $19.0 \mathrm{q}$ & $1.68 \mathrm{~s}$ \\
\hline $\mathrm{Ar}-\mathrm{OH}-1$ & - & $11.02 \mathrm{~s}$ \\
\hline $\mathrm{Ar}-\mathrm{OH}-2$ & - & $10.90 \mathrm{~s}$ \\
\hline $\mathrm{Ar}-\mathrm{OH}-4$ & - & $10.50 \mathrm{~s}$ \\
\hline
\end{tabular}

\section{RESULTS AND DISCUSSION}

Gramniphenols H(1) and four known fluorenone derivatives (2-5) (Fig. 1) were isolated from the $70 \%$ aqueous acetone extract of $A$. gramnifolia. Known compounds were identified as 1,4,5-trihydroxy-7-methoxy-9H-fluoren-9-one $(2)^{11}$, dendroflorin $(3)^{12}$, Dengibsin $(4)^{13}$, Denchrysan A $(5)^{14}$ by comparison of spectroscopic data with the literature.
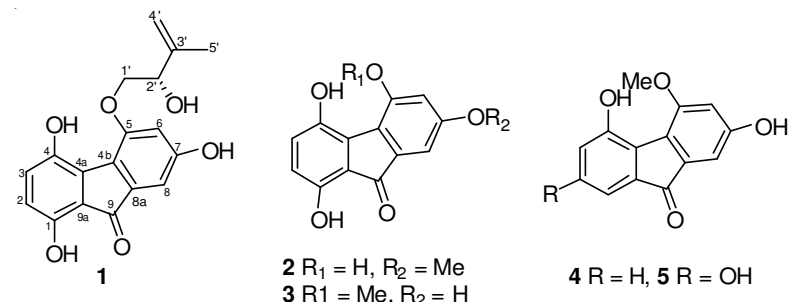

Fig. 1. Structures of derivatives fluorenone from A. gramnifolia
Gramniphenol $\mathrm{H}$ (1) was obtained as red gum. The molecular formula $\mathrm{C}_{18} \mathrm{H}_{15} \mathrm{O}_{6}$ was inferred by HRESI-MS at $m / z$ 327.0862 [M-H] $]^{-}$(calcd. (\%) for $\mathrm{C}_{18} \mathrm{H}_{15} \mathrm{O}_{6}, 327.0869$ ). The IR absorption bands indicated the presence of hydroxy (3325 $\left.\mathrm{cm}^{-1}\right)$, carbonyl $\left(1694 \mathrm{~cm}^{-1}\right)$ and aromatic ring (1612, $1547,1455 \mathrm{~cm}^{-1}$ ) and UV absorptions at 267, 320, $346 \mathrm{~nm}$ suggested a conjugated aromatic ring system. The ${ }^{1} \mathrm{H}$ and ${ }^{13} \mathrm{C}$ NMR spectra of $\mathbf{1}$ (Table-1) displayed signals for all $\mathbf{1 8}$ carbons and 16 protons, suggesting the presence of an 1,4,5,7-oxygenated fluorenone moiety ${ }^{11}$ (H-2, H-3, H-6, H-8 and C-1-C-9a), three phenolic protons $\left(\delta_{\mathrm{H}} 10.50,10.90\right.$ and 11.02) and a 2-hydroxy3-methylbut-3-enyloxy unit $\left[-\mathrm{OCH}_{2} \mathrm{CH}(\mathrm{OH}) \mathrm{C}\left(\mathrm{CH}_{2}\right)\left(\mathrm{CH}_{3}\right)\right]^{10}$ (H-1', H-2', H-4', H-5' and C-1'-C-5'). The location of the 2-hydroxy-3-methylbut-3-enyloxy unit at C-5 position was supported by the HMBC correlation observed between $\mathrm{H}-1^{\prime}$ $\left(\delta_{\mathrm{H}} 3.97\right.$ and 4.13$)$ and $\mathrm{C}-5\left(\delta_{\mathrm{C}} 156.6\right)$. The three phenolic groups were assigned to $\mathrm{C}-1, \mathrm{C}-4$ and $\mathrm{C}-7$ positions on the basis of HMBC correlations (Fig. 2). The $\mathrm{S}$ configuration at C-2' was assigned by a comparison of NMR and optical rotation data with those of stachylines $\mathrm{A}^{10}$, of which absolute configuration was established by the Mosher method.

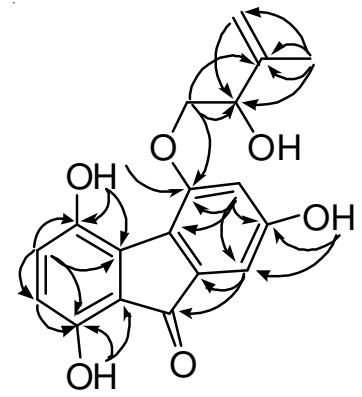

Fig. 2. Selected HMBC ( $)$ correlations of compound $\mathbf{1}$

Since certain of the phenolic compounds exhibit potential cytotoxicity ${ }^{15-17}$. Compound $\mathbf{1}$ was tested for their cytotoxicity against five human tumor cell lines (NB4, A549, SHSY5Y, PC3 and MCF7) using the MTT method as reported previously ${ }^{18}$. Taxol was used as the positive control. The results revealed that compound 1 showed low active $\left(\mathrm{IC}_{50}\right.$ values $>10$ $\mu \mathrm{M}$ ) for NB4, A549 and MCF7 tumor cell and showed modest cytotoxicity against PC3 and SHSY5Y cell with $\mathrm{IC}_{50}$ values of 6.18 and $4.25 \mu \mathrm{M}$, respectively.

\section{ACKNOWLEDGEMENTS}

This project was supported financially by the Excellent Scientific and Technological Team of Yunnan Higher Education (2010CI08) and the Yunnan University of Nationalities Green Chemistry and Functional Materials Research for Provincial Innovation Team (2011HC008).

\section{REFERENCES}

1. D.Y. Hong, Y. Lian, S. Shen and L.D., Flora of China; Chinese Science Press: Beijing, Vol. 73, p. 320 (1983).

2. K. Xiao, H.J. Zhang, L.J. Xuan, J. Zhang, Y.M. Xu and D.L. Bai, Studies Nat. Prod. Chem., 34, 453 (2008).

3. M.F. Liu, Y. Ding and D.M. Zhang, Chin. J. Chin. Mater. Med., 30, 353 (2005).

4. M.F. Liu, Y. Han, D.M. Xing, Y. Shi, L.Z. Xu, L.J. Du and Y. Ding, J. Asian Nat. Prod. Res., 6, 229 (2004). 
5. M.F. Liu, Y. Ding and L. Du, J. Chin. Trad. Herb Drug, 38, 676 (2007).

6. H. Zhu and Q.S. Song, Nat. Prod. Res. Dev., 20, 5 (2008)

7. A.S.C. Wan, R.T. Aexel and H.J. Nicholas, Phytochemistry, 10, 2267 (1971).

8. P.L. Majumder and S. Ghosal, J. Indian Chem. Soc., 68, 88 (1991).

9. Z.R. Gao, S.T. Xu, J. Wei, H.L. Shi, Z. Li and Q.F. Hu, Asian J. Chem., 25, 2747 (2013).

10. Q.F. Hu, B. Zhou, J.M. Huang, X.M. Gao, L.D. Shu, G.Y. Yang and C.T. Che, J. Nat. Prod., 75, 684 (2013).

11. Y.G. Chen, Y.P. Li, C. Qing, Y.L. Zhang, L.Q. Wang and Y. Liu, Food Chem., 108, 973 (2008).

12. C.O. Fan, W. Wang, Y.P. Wang, G. Qin and W.M. Zhao, Phytochemistry, 57, 1255 (2001).
13. S.K. Talapatra, S. Bose, A.K. Mallik and B. Talapatra, Tetrahedron, 41, 2765 (1985).

14. Q.H. Ye, W.M. Zhao and G.W. Qin, Nat. Prod. Res., 17, 201 (2003).

15. Y.L. Lu, X.S. Li, H.X. Mu, H.T. Huang, G.P. Li and Q.F. Hu, J. Braz. Chem. Soc., 23, 656 (2012).

16. X.M. Gao, Y.Q. Shen, L.Y. Yang, L.D. Shu, G.P. Li, and Q.F. Hu, J. Braz. Chem. Soc., 23, 1274 (2012).

17. Q.F. Hu, X.S. Li, H.T. Huang, H.X. Mu, P.F. Tu and G.P. Li, Helv. Chim. Acta, 95, 349 (2012).

19. T. Mosmann, J. Immunol. Methods, 65, 55 (1983).

THE INTERNATIONAL CONFERENCE ON PURE AND APPLIED CHEMISTRY (ICPAC-2014)

$$
23-27 \text { JUNE, } 2014
$$

\section{HOTEL SOFITEL MAURITIUS IMPERIAL RESORT \& SPA, MAURITIUS \\ (http://sites.uom.ac.mu/icpac/)}

\section{Theme of ICPAC-2014 is Crystallising Ideas: The Role of Chemistry}

For abstract submission: http://sites.uom.ac.mu/icpac/index.php/abstract

*Full papers (optional) will be peer reviewed and accepted papers will be collected in the book of proceedings to be published by Springer.

\section{Deadlines}

\author{
Workshop/Symposium proposal \\ Abstract submission (oral or poster) \\ Booking for accommodation \\ Early Registration \\ Full paper (optional)
}

\author{
31st December 2013 \\ 15th March 2014 \\ 1st April 2014 \\ 15th April 2014 \\ 1st October 2014
}

